\title{
NeW ZEALAND TRUSTEE INVESTING: REFLECTING ON MODERN PORTFOLIO THEORY AND THE ANCIENT DISTINCTION OF PRINCIPAL AND INCOME
}

\author{
F Philip Manns Jr*
}

\begin{abstract}
The New Zealand Trustee Amendment Act 1988 led the common law world in encouraging (perhaps requiring) trustees to use modern portfolio theory ("MPT") techniques when investing trust funds. A recent High Court decision essentially held that trustees should have engaged in MPT-based investment since 1972. Full integration of MPT principles into trust law affects many areas of trust administration, perhaps most prominently the ancient distinction of principal and income. In addition, renewed attention to careful drafting of a settler's investment and pay out intentions and greater investment diversification are likely consequences of MPTbased trust investing.
\end{abstract}

\section{INTRODUCTION}

Trust law invariably conjures up images of stodgy lawyers, peering up from dusty law books to advise still stodgier clients, mumbling words like "prudent" and "conservative". Conversely, the world of high finance evokes images of young, sharpminded investment bankers jumping about lightning fast computers, mumbling "correlation coefficients" and "capital asset pricing models". An odd fact of the late 1980s is the legislative demand in New Zealand and the United States that those two cultures merge, by requiring trustees to invest using the theory of efficient markets, or more

* Professor of Law, California Western School of Law, San Diego, California. During May to August 1997, I taught Trusts law at Victoria University of Wellington, pursuant to a faculty exchange program between California Western and Victoria University, and I thank both universities for their support of the program. While teaching, I came across the Mulligan case (pointed out to me by a student), and began considering the contrast between New Zealand's and the United States' incorporation of MPT into trust law. 
generally, Modern Portfolio Theory ("MPT"). MPT has been developed by academics (four of whom received Nobel prizes in Economics) and implemented by financiers. ${ }^{1}$

The New Zealand Trustee Amendment Act 1988 was the first enactment expressly to encourage trustees to use MPT, preceding enactments in the United States by a few years. The 1988 Act abandoned the "legal list" approach to trustee investment, historically favoured under English law, by which investments were confined to a list of authorised investments, ${ }^{2}$ and replaced it with an expanded "prudent person" standard, ${ }^{3}$ by which a trustee is to invest in a "portfolio" designed to maximize income, minimize risk, and maintain impartiality between income and remainder beneficiaries. ${ }^{4}$

Andrew Butler in an article in the Bond Law Review, "Modern Portfolio Theory and Investment Powers of Trustees: The New Zealand Experience", 5 well described the salient

1 John H Langbein "The Uniform Prudent Investor Act and the Future of Trust Investing" (1996) 81 Iowa L Rev 641, 642 ["Uniform Prudent Investor Act"].

2 The legal list approach, founded in English law, owes itself to abject failure when English trustees first began investing in company shares (equities). Following spectacular losses by trustees in South Sea Company shares in the early eighteenth century, the Chancery Court developed a restricted list of presumptively proper trust investments. Not until 1961 were English trustees permitted generally to invest in equities. "Uniform Prudent Investor Act" above n 1, 643 (citing A H Oosterhoff Trustees' Powers of Investment: A Study Prepared at the Direction of the Ontario Law Review Commission (1970)).

Prior to the enactment of the Trustee Amendment Act 1988, which came into force on 1 October of that year, New Zealand trustees were restricted to those investments listed in the Trustee Act and the governing trust deed. Investments of superannuation funds were also controlled between April 1983 and April 1990 by the Superannuation Schemes Regulations 1983. Under the regulations, trustees were provided with investment options in addition to those specified in the Trustee Act. Trustees were permitted, among other things, to invest in shares and other securities listed on any exchange registered under the Sharebrokers Act 1908.

3 The states of the United States typically rejected the "legal list" approach in favour of the "prudent man" (later gender-neutralized to prudent person) standard developed in Harvard College v Armory 26 Mass (9 Pick) 446 (1830). Yet, under that standard, equity investments in shares of anything other than the bluest of blue chips often were tainted as "speculation." Consequently, states in the US have had to enact MPT permissive statutes, often patterned on the Uniform Prudent Investor Act, or have their courts interpret common law in light of MPT, as suggested by the Restatement (Third) of Trusts (Prudent Investor Rule) s 227, which mandates a portfolio approach.

4 (14 July 1988) 490 NZPD 5121-5123 (Rt Hon Sir Geoffrey Palmer); Report of Joint Working Party Trustee Investment: The Prudent Man Approach? (New Zealand Department of Justice, June, 1986). This unabashed incorporation of American culture contrasts with a commentary that I read while teaching in New Zealand. "We Don't Know How Lucky We Were" New Zealand Herald, Auckland, July, 1997, ("I foresee the gradual disintegration of our post-colonialist, egalitarian society under the assault of American popular culture preaching greed and violence, beamed in by satellites...").

5 (1995) 7 Bond L R 119 ["The New Zealand Experience"]. 
principles of MPT, the process of enactment of the Trustee Amendment Act 1988, and offered a general critique of the Act. Butler spends some time deciding whether the Act (1) permits, (2) encourages, or (3) mandates the use of MPT, and concludes that the Act encourages MPT for all trusts and may mandate it for large trusts. ${ }^{6}$

Since Butler wrote, a High Court decision essentially ruled that New Zealand trustees were required to utilize modern portfolio techniques even before enactment of the Trustee Amendment Act 1988. The decision in Re Mulligan ${ }^{7}$ ("Mulligan") has been widely discussed and criticized, for Mulligan is an extraordinary case study of the squeeze brought to bear on a trustee who is required to maximize income, minimize risk, and maintain impartiality.

The Mulligan court found that trustees breached their duty of impartiality to remainder beneficiaries by failing to protect the property of the trust from inflation. When calculating damages, which is an exercise in deciding what the trustees should have done, the court essentially required the trustees to have engaged in MPT-based investment since 1972. The court decided that in 1972, when the life tenant "had no need to maximise her income from every possible source", 8 the trustees should have shifted from $100 \%$ fixed income investments to $40 \%$ equities, and thereafter should have earned a return on those equities equal to $75 \%$ of the return of the Barclays Index. ${ }^{9}$ In MPT jargon, the court told the trustees that they should have assembled a portfolio with a beta of $0.75 .^{10}$

The case is a significant interpretation of the Trustee Amendment Act 1988, for it found the Act of such little significance. ${ }^{11}$ Rather than reading the Act to have made great changes, the court found it declarative of prior law regarding both the obligation of the trustees to maintain the real value of trust capital and the obligation of trustees to utilize MPT to increase equity returns. ${ }^{12}$

6 "The New Zealand Experience" above n 5, 147-150.

7 Re Mulligan (Deceased) [1998] 1 NZLR 481 [Mulligan].

8 Mulligan above $\mathrm{n} 7,491$.

9 In 1991, the NZSE 40 Index replaced the Barclays Index.

10 See infra note 47 and accompanying text.

11 Two commentators, one of whom was a defence expert in Mulligan, suggest that Mulligan is based on unique circumstances, and does not create a general rule that trust property should be invested in equities. R L Davis and G Shaw Trustee Investment: The Prudent Person Approach (2 ed, Butterworths, Wellington, 1997) 23

12 See also Jones above n 2, 706. The Court found the amending Act as declaring existing law, rather than changing it. "As I take the view that the amendment to the Trustee Act in 1988 is essentially a 
Not surprisingly, the Mulligan decision rocked the New Zealand trusts management community. A commentator declared, "the case is a milestone for the trust and investment industries. The obligation to invest a portion of a trust estate in shares needed to be confirmed by the common law and, subject to a possible appeal, it has been". ${ }^{13}$

Unlike the court in Mulligan, the Joint Working Party Report on the Trustee Amendment Act 1988 did not regard the issue of maintaining real value of trust capital as settled, and intentionally avoided settling it. Calling the issue one on which direct legal authority was scarce, the Report stated: ${ }^{14}$

We do not think that in this Report we should recommend the enactment of any such obligations [to maintain the real value of trust capital], since the issue requires study in its own right and should not be dealt with by way of side-wind in a report on the prudent man approach.

Nonetheless, the Mulligan court decided, based largely on the testimony of the defendant trust company's employees, that the standard of prudence prevailing within the industry throughout the relevant time had been to protect trust capital from inflation. ${ }^{15}$ The court rejected the testimony of defence experts that industry practice during the relevant time (1972 to 1990) was to do "nothing positive" to account for inflation. ${ }^{16}$ The

clarification of the common law principles previously governing a trustee's obligations relating to the investment of moneys, I do not propose to enter upon a discourse as to the standard of care required of a trustee before that amendment. Notwithstanding that much of Perpetual's conduct falls to be judged in accordance with the law prior to October 1988, a comparison would be of little assistance in the circumstances of this case. For myself, I am content to apply the 'prudent person' test. Perpetual, I believe, discharged its duties to that standard throughout the period under consideration".

13 Jack Hindin "New Factors for Trustees to Weigh", The National Business Review Wellington, New Zealand, 2 August 1996, 26. Other commentators expressed greater alarm. "Lawyer and estate planner Ross Holmes said the case had frightening implications for the many ordinary New Zealanders who became trustees" "Estate Ruling Frightening for Trustees" Sunday Star-Times, 21 July 1996, Business Section 2. "[Justice Pankhurst's] judgment has caused ruffles in the commercial and professional communities, with fears that it could lead to other claims." Another lawyer, who did not want to be named, said he believed the judgment would generate further litigation. "I suspect there is a lot of discussion going on because a lot of estates may not stand up to much scrutiny." Alan Williams "New Trustee Claim Believed Based on Mulligan-PGG Case" Christchurch Press, Christchurch, New Zealand, 17 July 1996, Business Section at 26.

14 Report of Joint Working Party, above n 4, 12.

15 The court noted, "That the three PGG Trust officers separately recognised the risk posed by inflation and recommended a remedial course of action is in my view not just significant, but decisive, evidence." Mulligan above n 7, 504.

16 Mulligan above $\mathrm{n} 7,504$. 
court went the further step of announcing that had industry practice been as the defence experts said, the court would have considered seriously the claim that the entire industry fell below the required standard. ${ }^{17}$

In its most narrow sense, Mulligan holds that the trustees failed their duty of impartiality ${ }^{18}$ by favouring the life income beneficiary over the remainder beneficiaries. The co-trustees, PGG Trust Limited (PGG) and Mrs Mulligan, life income beneficiary and widow of the deceased settler, invested solely in fixed income securities, thereby preserving the nominal value of the trust property and not its real value. ${ }^{19}$ In 1965 , when financial investment by the trust began, the trust property was $\$ 108,000$; in 1990 , when Mrs Mulligan died, the trust property was $\$ 102,000$. While the numbers of dollars of trust property (nominal amount) essentially was maintained throughout administration of the trust, inflation in New Zealand between 1965 and 1990 had been substantial. The inflation equivalent value of $\$ 108,000$ in 1965 was $\$ 1,368,000^{20}$ at time of trial in Mulligan. Quite obviously, deciding whether the trustees were required to maintain either nominal value or "real value" would have dramatic consequences.

On that point, the defendant trustee investment company, PGG, was hoist by its own petard. While its experts opined that, under the prevailing standard of care, trustees during 1965-1990 were required only to maintain nominal value, PGG's own employees had demonstrated otherwise. Each of the three PGG employees serially assigned to administer the trust had recognized the risk of inflation and had recommended the remedial action of investing in equities, but ultimately had deferred to the co-trustee-life

17 Mulligan above n 7, 504 (citing McLaren Maycroft \& Co v Fletcher [1973] 2 NZLR 100; Edward Wong Finance $v$ Johnson Stokes \& Master [1984] AC 296).

18 G E Dal Pont and D R C Chalmers Equity and Trusts in Australia and New Zealand (Law Book Company, North Ryde (NSW), 1996) 471-476.

19 Investing in fixed income securities cheats the remainder beneficiaries because the principal amount of the debt, the thing to which the remainder beneficiaries are entitled, remains constant while inflation whittles away its purchasing power. That is the sense in which the Mulligan trustees were regarded to breach their duty. See also Re Greenwood [1988] 1 NZLR 197, 204 (in which a court approved a sale of farming estate and noted that the trustees expressly stated that they did not intend to invest in fixed income securities which would result in the capital of the trust not keeping pace with inflation). Yet, investing in fixed income securities cheats all beneficiaries because the natural alternative to it, investing in equity securities for capital gain, historically exceeds the return on fixed income securities by 7 to $8 \%$. See infra note 32 and accompanying text. Thus all lose, including the trustee whose fees probably are a percentage of the corpus of the trust.

20 Mulligan above $\mathrm{n} 7,483$. The court refers to $\$ 1.368$ million as the value "in today's terms." It is not clear whether it meant in 1990 when the trust terminated or during the 1996 time of trial. By contrast, the inflation adjusted of \$US 108,000 in 1965 was approximately \$US 540,000 in 1996. US Dept of Labor, Bureau of Labor Statistics (http:/ / stats.bls.gov). 
tenant's demand that investment remain solely in fixed income investments. Thus, PGG's employees' own testimony had established the industry practice of investing in equities to combat inflation, and the question devolved to whether, in this case, PGG was entitled to regard the intransigent opposition of Mrs Mulligan as sufficient reason not to diversify into equities. ${ }^{21}$ The court said no, finding that by 1972 PGG either should have persuaded Mrs Mulligan (perhaps suggesting she take advice from her solicitor) or, failing that, filed a court action seeking direction. By failing to diversify into equities, the value of the capital had eroded and the trustees, both PGG and Mrs Mulligan, had breached the duty of impartiality.

As a duty of impartiality case, Mulligan stands in contrast to the 1977 High Court decision in Re Lyell. ${ }^{22}$ In Re Lyell ("Lyell"), the trustees sought court permission to sell the trust property, Balvonie, a Nelson estate which "though still bearing a semblance of earlier grand times in New Zealand" 23 was completely run down. The trustees proposed to invest the sales proceeds in fixed income securities, paying $10 \%$ per annum. A guardian ad litem, appointed to represent the remainder beneficiaries, consented both to the sale and to the investment in fixed income securities, but he sought an order requiring one-

21 PGGs employees testified that whenever they raised the matter with Mrs Mulligan, she "was absolutely horrified at the prospect of investing in companies," yet at her death, Mrs Mulligan owned an extensive share portfolio. In yet another irony in a case full of them, PGGs experts testified that portfolio investing was too avant garde for trustees to understand and follow from 1966 to 1990, yet Mrs Mulligan understood and followed it throughout that period. She effectively diversified into three pieces: real estate owned in her name, shares owned in her name, and fixed income investments through the life interest in the trust. She was a skilled investor, inheriting $\$ 14,000$ from her husband (in 1949, but paid to her $1 / 2$ in 1954 and $1 / 2$ in 1965) and leaving an estate of $\$ 686,000$ at her death in 1990 . Her relatives inherited her fortune, while the residual beneficiaries of the trust, her husband's relatives, received a parsimonious distribution of trust capital, whittled away by inflation.

The Mulligan case suggests the possibility of the following conundrum. A widow, who is life income beneficiary and co-trustee of a trust, designs to consume the trust's capital by forcing her co-trustee to agree to fixed income investments. She then uses her own money to diversify, buying real estate and shares. Whenever the other trustee asks the widow about her other income, she becomes enraged, and through a combination of acting "dumb like a fox" and persistent badgering of the other trustee about fees, the widow succeeds, the other trustee is more than happy to "ignore" that hornets nest. Strangely, the widow does not consume the "trust" income, so the net effect is to "transfer" capital from the trust's remainder beneficiaries to the widow's heirs. When the trust's remainder beneficiaries succeed in a breach of trust action against the widow's estate, the widow's "transfer" is undone to the extent of the damages, and whatever the co-trustee pays in damages is a windfall to the competing camps of trust beneficiaries and widow's heirs. One can not help but wonder what the settler would have thought. He died leaving a young widow. He should have given better direction in the trust.

22 Re Lyell (deceased) [1977] 1 NZLR 713.

23 Re Lyell above n 22, 714. 
third of the annual interest income be capitalized, that is, treated not as income for the life income beneficiary but as trust property for ultimate distribution to the remainder beneficiaries. The guardian argued that, without such capitalization, the "purchasing power of the capital fund of the estate would be . . systematically whittled down by the effects of inflation." 24 That whittling was no small matter, as the inflation rate prevailing at the time of the Lyell decision was 10 to 11 per cent. ${ }^{25}$

The court rejected the guardian's request, because such an order would vary beneficial interests in the trust and would exceed the court's jurisdiction. The court then tossed out a platitude hardly consistent with its decision:

While I cannot, therefore, make the order of the kind that Mr Wild [the guardian ad litem] suggested, there is some substance in his argument for my expressing the opinion that trustees nowadays, faced with the inflationary tendencies so graphically illustrated in counsel's figures, should carefully watch the modes of investment that they adopt on behalf of beneficiaries.

The conflict between dictum and decision is vast; the court reminds trustees of a duty of impartiality the violation of which the court (and seemingly therefore the trustee) appears powerless to stop. For instance, in Mulligan, a Lyell-like trustee (investing solely in fixed-income securities) was surcharged mightily for investing exclusively in fixed income securities, yet under Lyell the Mulligan trustees could not have equitably apportioned the trust's investment return to income and principal, for that would vary the beneficial interests of the trust. Consequently, the two cases establish that trustees must ensure that they earn impartial amounts of income and principal; trustees cannot earn "return" under MPT principles (whether denominated "principal" or "income") and then equitably apportion it between beneficiaries.

Wooden application of the ancient distinction of principal and income obstructs MPT trust investing, and places trustees between Scylla and Charbydis. ${ }^{26}$ MPT investing and

24 Re Lyell above $\mathrm{n} 22,715-716$.

25 At that rate of inflation, the value of money is halved approximately every seven years.

26 Butler identified the three areas: (1) failure to address conclusively the extent to which investment management can be delegated by the trustee, (2) an overbroad anti-netting rule, and (3) complete failure to consider how the MPT affects the duty of impartiality. "The New Zealand Experience" above $n$ 5, 142-147.

The first two of those points strike me as less serious, because a court easily can interpret existing trust law in harmony with MPT. New Zealand already permits a broad delegation of trustee duties, and the High Court decision in Jones $v$ AMP Perpetual Trustee Company NZ Ltd [1994] 1 NZLR 690, grants near absolute immunity to a trustee who delegates investment responsibility. As well, the Act's overbroad anti-netting rule (by which a court could relieve a trustee from an investment decision made in breach of trust by offsetting the loss against any other gain, whether or not both were related to a common investment strategy) is not inconsistent with MPT, because 
the duty of impartiality are flip sides of the same coin. MPT addresses how the trustee should earn income; the duty of impartiality addresses how she should pay it out to the beneficiaries. Surprising agreement exists on the wisdom of MPT investment, as New Zealand, states of the United States, and other jurisdictions either encourage or require it. Considerably less agreement exists on how to dovetail MPT investing with impartiality among beneficiaries. In the United States, the Restatement (Third) of Trusts (Prudent Investor Rule) mandated MPT for trustee investment, and soon thereafter, a draft Revised Uniform Principal and Income Act hoped to revise the trust payout rule to eliminate artificial distinctions between principal and income. The draft proposal, despite the effort of the reporter, did not succeed, and the final version retains the ancient distinction of principal and income with a modest equitable apportionment provision designed to permit small adjustments. ${ }^{27}$ Thus, the law in the states of the United States and in New Zealand suffers from the same structural incompatibility between MPT investing and principal-and-income-based payouts.

The structural incompatibility results because portfolio theory (and the sharp-minded academics/ investment bankers who developed it) does not care whether a dollar of return from an investment is called "income" or "principal" or "return of capital" or anything else. Portfolio theory seeks total return, and a dollar is a dollar is a dollar. Consequently, any requirement that portfolio return occur in measured portions of "income" and "principal" conflicts with MPT's indifference to the distinction.

The settler of a trust can, and near universally should, override the default distinction of principal and income. These overrides come in two modes. One mode is to grant discretion $^{28}$ to the trustee to (1) decide what each beneficiary will receive (rather than giving income to one and principal to another), (2) invade principal, or (3) decide what is

under it all investments are related to a common investment strategy so all loses should be netted. "The New Zealand Experience" above n 5, 143-144 (citing New Zealand Law Society Submissions on The Trustee Amendment Bill 1987, 19 February 1988, 2). The defect in the Act is that a trustee not using MPT (and following Mulligan it is a small class of trustees who are not required to use MPT) gains a windfall through a newly overbroad anti-netting rule that he did not have prior to enactment of the 1988 Act. While a defect in drafting, the overbroad anti-netting rule does not hinder trustee use of MPT, it grants a windfall to non-portfolio trustees. Further, given the power of New Zealand courts to relieve trustees of breaches under s 73, the power of a court to apply an "overbroad anti-netting rule" always has existed.

27 Joel C Dobris "Why Trustee Investors Often Prefer Dividends to Capital Gain and Debt Instruments to Equity A Daunting Principal and Income Problem" (1997) 32 Real Prop Probate \& Trust J 255.

28 The discretion can be either reviewable or nonreviewable ("sole discretion"). Note that while courts always retain some residual review over trustees granted nonreviewable discretion, still the grant of "sole" discretion to the trustee puts the chances of litigation at a minimum. 
principal and income. The other mode of override is for the settler to express the life beneficiary's interest as an annuity ( $\$$ x per year for the rest of her life) or as a unitrust interest ( $y \%$ per annum of the value of the trust either as valued initially or re-valued annually). Only when one of these overrides is chosen by the settler is the trustee free to focus on an investment policy of after-tax, total return as individual investors do. ${ }^{29}$

Absent settler direction to the contrary, the trustee must earn return in measured portions, notwithstanding the glaring inconsistency between it and direction to trustees to invest using MPT. A stark incongruity results because the principal/income payout rule persists in face of near-universal acceptance of MPT. Stark incongruities can persist only if the rule that otherwise would be expected to yield (here the ancient distinction of principal and income) draws staying power from contexts outside the context in which the incongruity arises. That outside context for the principal/income payout rule is a deep-seated cultural disinclination to consume more than the annual harvest. The mystical staying power of the principal/income distinction (both in New Zealand and the United States) suggests it is pre-legal, resonating from an agricultural memory of crops and soil. As such, the most natural reform of the payout rule would be a shift to a unitrust interest, by which the income beneficiary annually is entitled to a fixed percentage of the trust assets, with the assets revalued annually. This is the model in the charitable area and has been suggested in the private area. ${ }^{30}$

When discussing the practical future effect of MPT on trust investing, John Langbein noted eight areas: greater use of equities; more pooling, less individual security selection; international investing; derivatives; reduced deference to paper trail; increased scrutiny of uneconomic settler instruction; fractionation of trusteeship; and principal and income. I will discuss six of those that have particular application to New Zealand.

Greater Use of Equities. Research has shown that returns on equities exceed all other asset classes. For the U.S. markets for the period 1926 to 1996, small company stocks annually returned $17.7 \%$ on average; large company stocks $12.7 \%$; long-term corporate bonds $6.0 \%$; long-term government bonds 5.4\%; intermediate government bonds $5.4 \%$; inflation averaged $3.2 \% .{ }^{31}$ Consequently, equities offer about a 7 to $8 \%$ annual premium over other investment. ${ }^{32}$

29 Edward C Halbach "Trust Investment in the Third Restatement" (1992) 77 Iowa L Rev 1151.

30 Robert B Wolf "Defeating the Duty to Disappoint Equally: The Total Return Trust" (1997) 32 Real Prop Probate \& Trust J 45, 60-63 ["Defeating the Duty"].

31 Ibbotson Associates Stocks, Bonds, Bills, and Inflation 1997 Yearbook ("Ibbotson 1997 Yearbook") Table $2-1,33$.

32 "Ibbotson 1997 Yearbook" Table 8-1, 161. 
More Pooling, Less Individual Security Selection. At bottom, MPT posits that selection of particular equities yields no additional return. Although counter-intuitive at first blush, the futility of trying to pick individual stocks becomes apparent on reflection. Under the efficient capital market hypothesis (which largely has been proven by empirical study), ${ }^{33}$ the equity markets are highly efficient in assimilating all publicly available information about a security. For each transaction, a skilled buyer and skilled seller have considered all publicly available information, have made opposite judgments about whether the current price properly reflects future performance of the security, and have thereby established the market price. Consequently, no investor with published information can outperform the market by picking undervalued securities. ${ }^{34}$ Investors with non-publicly available information routinely outperform the market, but that is why most countries forbid insider trading. ${ }^{35}$ Thus, without insider information (and an inclination to break the law), an investor is unable to pick undervalued securities.

The data in the United States strongly supports the efficient capital market hypothesis, $^{36}$ as few investors are able to beat the market average, and even fewer consistently do it. For the ten-year period from 1988 through 1997, the US stock market, measured by the S\&P 500, annually returned $18.1 \% .{ }^{37}$ During that ten-year period, 272 "growth" mutual funds continuously operated in the US and annually returned $16 \%$. Fifty-four "aggressive growth" mutual funds continuously operated and annually returned 14.8\%; seventy-four "small capitalization" mutual funds continuously operated and annually returned $16.6 \% .{ }^{38}$ Much of the difference between the market average, which over a large number of funds and long period of time would be expected to be the market average, and the average fund return can be explained by the funds' expenses, which typically are between 1 and $2 \%$. Within each group of funds, some did outperform the market average, but most did not. Since there seems no reliable way ex ante to decide

33 Jonathan R Macey An Introduction to Modern Financial Theory (1991, American College of Trust \& Estate Counsel Foundation) ("Modern Financial Theory") 40. For a critique see Robert A Levy "The Prudent Investor Rule: Theories and Evidence" (1994) 1 Geo Mason L Rev 1, 16-18.

The efficient capital market hypothesis described in the text is the "semi-strong" form. Under the strong form, we hypothesize that the markets are so efficient that not even investors with inside information can profit from trading on it. Empirical evidence refutes the strong form. "Modern Financial Theory" above n 33, 37. 
which fund manager will outperform the average, ${ }^{39}$ and since we know that the average fund will underperform the market average (if for no other reason that they have expenses of 1 to $2 \%$ ), the conclusion becomes irresistible that investors should forego picking individual stocks (or individual fund managers) and instead invest in "index" funds that mechanically invest to match the market index, and do so with lower expenses (in the 0.2 to $0.4 \%$ range).

Such passive index funds are a natural outgrowth of MPT, and were introduced in the United States in the mid-1970s. Presently, there are 172 US index funds with assets of \$US 157 billion. ${ }^{40}$ Passive index funds were introduced in New Zealand with TeNZ in June 1996, and expanded quickly, growing to $\$ 750$ million by November $1997 .{ }^{41}$ Currently offered in New Zealand are funds to follow various indexes, including the NZSE 10, NZSE 30, NZSE 40, NZSE SCI, ASX 20, and Morgan Stanley Capital Index. ${ }^{42}$ Expenses, at 0.4 to $1.25 \%$ annual management fees plus an entry fee of 1 to $6 \%$, far exceed expenses for US passive index funds, but one can hope that the expenses will decrease over time, as increasing size creates efficiencies.

Although the data in New Zealand is more limited, it similarly supports the efficient capital market hypothesis; active fund managers return less than the market. In a simulation prepared by IPAC Securities and reported in the Sunday Star-Times, the return on the NZSE40 Gross Index exceeded the return earned by the average managed fund for all but one of the five annual periods 1991 to 1996.

In fact, in New Zealand the irresistible theoretical conclusion (following acceptance of the efficient capital market hypothesis) in favor of index funds grows only stronger when

39 Strategies abound for identifying above-average fund managers. Here is one recently reported, the so-called "persistency of performance" model, developed by Sheldon Jacobs, publisher of The NoLoad Fund Investor newsletter. It works as follows: At the end of each year, you pick out the topperforming diversified no-load stock fund for the year, and invest money in it for the following year. Come the ensuing 1 January, you move on to the next winner of the annual performance race. Nondiversified funds, including sector funds and specialized operations such as gold funds, are expressly excluded from consideration because they are so exposed to the changing whims of the marketplace. Jacobs, based in Irvington-on-Hudson, NY, back-tested the system to 1975, and has followed it in real time since 1992. He reports: Over 22 years, my top-rated selections outperformed the average diversified no-load in 15 instances. One year was a tie, and in the remaining six years the strategy underperformed the average no-load. Overall, the strategy has averaged 23 per cent a year versus 15.2 per cent for the average no-load. "Jacobs Rules Are Based Strictly on Persistency of Performance" San Diego Union-Tribune San Diego, 21 February 1998.

40 Guy Halverson "Index Funds Lock In the Ups, But Also Any Downs Ahead" The Christian Science Monitor, 9 February, 1998, B6.

41 Sunday Star-Times, 16 November 1997, Business section 2.

42 "Passive Funds What's the Story?" (1997) 13 NZ Investment J 1 (April-May 1997). 
the New Zealand tax benefit for index funds is added. Passive funds have obtained binding Inland Revenue Department rulings that tax is not payable on gains realised from the sale of shares held by the funds. ${ }^{43}$ To get over the tax hurdle, an actively managed fund has to earn half as much again of the expected capital gain that a tax-free passive fund would make (when there is a tax rate of 33 per cent) to match its return to investors. ${ }^{44}$ Perhaps New Zealand is blessed with particularly prescient active fund managers, but it appears highly improbable that the average active fund manager can outperform the market index by both the $50 \%$ necessary to cover the tax advantage and the increased amount of expenses. ${ }^{45}$

International Investing. Diversification is a costless mechanism to increase return, both within markets and across markets. Within a market, like the New Zealand Stock Exchange, diversification is the mechanism that permits an investor to earn the market rate of return. Absent diversification, the investor faces firm-specific risk - the risk that the chosen firm will underperform the market because of reasons specific to that firm. But of course the underdiversified investor, who buys shares in one or a few companies, also has the possibility of exceeding the market rate of return, if she happens to pick shares that subsequently perform better than the market average, but on average she will not. The market does not reward persons who underdiversify; the rate of return of a company's shares is the same for all investors for the same period of time; those who own only Telecom are not rewarded with a higher rate of return on their Telecom shares compared to those Telecom shareholders who also own shares in other companies. Because firm-specific risk is not compensated, an investor in a given market should diversify away firm-specific risk and earn the market rate of return.

In addition to firm-specific risk, the other risk in investing is market risk - the aggregate of risks that establish the market rate of return. Market risk cannot be

43 initially opposed their development. Apparently some fund managers threatened to blacklist brokers who dealt with TeNZ. Garry Sheeran, "TeNZ Should Appeal to Investors" Sunday StarTimes, 26 May 1996, 3. Soon thereafter, many fund managers decided to join rather than fight, "Passive Investment Funds Set to Treble" The Dominion, Wellington, 3 May 1997, 14. Presently, active fund managers have sought to justify themselves as superior to passive funds in down markets. "Index Funds Shine May Fade in Time" Sunday Star-Times, 3 November 1996, 4. ("Call me old-fashioned but I'm prepared to tolerate some under performance from active fund managers for the comfort of knowing that there is an experienced professional of proven competence at the controls."). The theoretical basis of MPT does not distinguish between up and down markets. If an investor wants less volatility, rather than an active fund manager, the investor should choose a passive fund with a beta of less than 1. "Modern Financial Theory" above n 33. 
diversified away within a market, but can be diversified away by investing in securities in other markets. Home country and non-home-country securities more often are negatively correlated than are home country securities. ${ }^{46}$ Although that fact comes as a surprise to individual Americans, who had not invested abroad until recently, for New Zealanders international investing has been more common, and MPT will only increase its incidence. Analogizing from single markets to world-wide markets in the broadest sense, world-wide diversification would ensure that the investor earns the world-wide equity market rate of return. If world-wide equity markets are semi-strong efficient (a big if), as the United States markets have been shown, then investors should completely diversify world-wide, for investors would not be compensated for individual market risk, just as investors in a given market are not compensated for firm-specific risk.

Under MPT, the role of professional advisers is not to try to outperform the market, for on average they will fail. However, they could have a role in assembling portfolios with various average beta coefficients. ${ }^{47} \mathrm{~A}$ beta coefficient is a statistical measure of how a particular security varies with general market fluctuations. It can be interpreted as the change in asset return which has accompanied a one percentage change in market index return. ${ }^{48}$ Thus, a security with a beta of 1.0 moves up $10 \%$ when the market moves up $10 \%$ (and down 10\% when the market moves down 10\%); a security with a beta of 0.8 moves up $8 \%$ when the market moves up $10 \%$ (and moves down $8 \%$ when the market moves down 10\%); and a security with a beta of 1.2 moves up $12 \%$ when the market moves up 10\% (and moves down 12\% when the market moves down 10\%). The beta of a portfolio of securities is the weighted average of the betas of the securities within the portfolio.

Consequently, investors who want more safety in down markets and are willing to sacrifice return in up markets should chose portfolios with betas of less than one, and investors willing to risk more in down markets for greater return in up markets should chose portfolios with betas greater than one. Thus, rather than trying to select individual securities, investment managers could offer fully diversified portfolios of various average beta coefficients.

Increased Scrutiny of Uneconomic Settler Conditions. Nearly all default trust rules yield to contrary direction by the settler, including directions regarding investment. ${ }^{49}$ For instance, it seems common in New Zealand for settlers to have denied the trustee power

\footnotetext{
46 "Uniform Prudent Investor Act" above n 2, 659. "Modern Financial Theory" above n 34, 50.

47 "Modern Financial Theory" above n 33, 49.

49 Trustee Amendment Act 1988, s 13D.
} 
to sell a family farm, which effectively is a direction that the trust property remain invested in the farm. That custom is shown in the number of cases in which trustees denied power of sale have sought and obtained judicial grant of the power of sale under section 64 or section $64 \mathrm{~A}$ of the Trustee Act 1956. Yet, by authorizing sales in face of settler direction to the contrary, the cases explicitly have recognized the investment harm in underdiversification. Increased emphasis on MPT-based investment will accelerate that trend, as MPT demonstrates the value of diversification and that diversification can be achieved at little cost. Consequently, courts will become even more likely to overturn uneconomic settler conditions. ${ }^{50}$

Fractionation of Trusteeship. MPT-based investment requires trustees to invest in larger portfolios or to invest in funds managed by others, yet trustees are under a duty not to delegate the exercise of a trustee's powers, authorities, or discretions. ${ }^{51}$ Consequently, the question arises how trustees properly can take advice on investment yet not improperly delegate their responsibilities. The integration of MPT-based investment with the advice/delegation paradigm is an obstacle to MPT-based investment. ${ }^{52}$ As Butler noted, "[p]ro portfolio legislation would need to address the subject of delegation in a head-on fashion." 53 In the United States, where the nondelegation doctrine had been employed even more strictly than in New Zealand and the Commonwealth, ${ }^{54}$ the MPTfocused reforms in the Restatement and Uniform Prudent Investor Act legitimated delegation of investment. ${ }^{55}$ In New Zealand, section 29(1) permits employment of agents, and if the agent is employed in good faith, the trustee is not liable for losses incurred by the agent, ${ }^{56}$ but it is not clear whether investment selection is the sort of act for which an agent can be hired under section $29(1) .{ }^{57}$

While the interpretative question lingers in section 29(1), I argue that the High Court in Jones $v$ AMP Perpetual Trustee Co NZ Ltd ${ }^{58}$ essentially held that a trustee is not liable for

50 "Uniform Prudent Investor Act" above n 1, 665.

51 Dal Pont and Chalmers above n 18, 463; Jones above n 2, 690, 704.

52 "Uniform Prudent Investor Act" above n 1, 665-666. "The New Zealand Experience" above n 5, 134-137. "Trust Investment in the Third Restatement" above n 29, 1174.

53 "The New Zealand Experience" above n 5, 136.

54 "The New Zealand Experience" above n 5, 135-136.

55 "Uniform Prudent Investor Act" above n 1, 666.

56 Dal Pont and Chalmers above n 18, 464.

57 "The New Zealand Experience" above n 5, 135.

58 Jones above $\mathrm{n} 2$. 
following an index investment strategy. In that case, the trustee, Perpetual, invested in a "life insurance policy," the premiums of which were invested in a unitised investment linked fund, managed by the insurer. The insurer/fund manager heavily invested in shares and lost substantial value in the October 1987 sharemarket crash. ${ }^{59}$ Among other claims, trust beneficiaries alleged that the trustees improperly delegated the power of investment to the fund manager, but the court disagreed, focusing on the status of the investment. The trust deed expressly permitted investment in life insurance policies, ${ }^{60}$ among many other investments, including New Zealand mortgages, New Zealand shares, New Zealand unit trusts, and New Zealand land, ${ }^{61}$ and the court concluded that if a permitted investment is chosen, no improper delegation results. "Express authorisation of this kind means that Perpetual was doing what it was entitled to do, and that cannot be an improper delegation of authority."62 Further, the court reiterated its conclusions when the trustee's actions were measured against the "prudent person" rule of section 13B; consequently, a decision to invest in managed funds is not a wrongful delegation under either the pre-1988 law or the post-1988 prudent person law. ${ }^{63}$ After deciding that a fund was a proper investment, the court concluded that a drop in the sharemarket, even a substantial one, is not grounds for liability. ${ }^{64}$

To me, Jones $v$ AMP Perpetual Trustee Co NZ Ltd effectively immunises trustees from liability for investing in index funds. First, unit trust funds as a class are prudent investments and do not contravene the nondelegation rule. Second, the trustee who invests in a unit trust fund is not required, or apparently even expected, to review the constituent investments making up the unit trust fund. To reject the trust beneficiaries' argument that Perpetual had failed to review the investment fund, the court noted evidence of Perpetual's review of the performance of the "fund" and Perpetual's consideration of alternatives to investment in the "fund". 65 No suggestion was made that Perpetual should have reviewed constituent investments of the fund, and it appears that Perpetual lacked authority under the investment contract to make such suggestions. Perpetual could not tell the manager to sell (or buy) this or that security within the fund;

59 Jones above n 2, 695.

60 Jones above n 2, 705.

61 Jones above n 2, 695.

62 Jones above $\mathrm{n} 2,705$.

63 Jones above n 2, 706-707.

64 Jones above n 2, 707 (citing Stark v United States Trust Co of New York 445 F Supp 670 (1978) and De Bruyner Equitable Life Assurance Society 920 F 2d 457 (7th Cir 1990).

65 Jones above n 2, 709 . 
Perpetual could decide only to stay invested in the fund or to sell it, ${ }^{66}$ and under the court's decision, Perpetual's review properly was limited to that question. Third, a trustee deciding to stay invested in a fund is not liable for a general market decline. Fourth, the court took the further step of saying that even if it were wrong in exonerating Perpetual from any breach of trust, it would exempt it from liability under section 73 . The court's summary of the case gives an able defence for index investing. ${ }^{67}$

In this case, I do not doubt that Perpetual acted honestly and reasonably; it made proper inquiries and took advice, it directed its mind to the critical question of what was in the best interests of the trust, it kept the investment under review, it invested the trust fund with a reputable life insurance company which had performed, and continued to perform, relatively well as a fund manager, the A Unit was a particularly suitable form of investment for a fund the size of that in issue, Perpetual did no more nor less than what any number of other superannuation funds were doing in investing in a life policy with AMP and specifying the A Unit as the vehicle for the funds management, and the A Unit performed well. The performance of the A Unit only declined with the sharemarket crash of October 1987, an event which most commercial and professional persons and institutions failed to predict. In all this there is no evidence of any lack of good faith or aberrant or unreasonable behavour.

Increased use of MPT-based investing, particularly by investing in index or other managed funds, will necessitate decision (either by statutory amendment or court decision) on whether investment selection is the sort of act for which an agent can be hired under section 29(1), yet the decision in Jones $v$ AMP Perpetual Trustee Co NZ Ltd provides real comfort to trustees using MPT-based investing.

Principal and Income. As noted earlier, MPT exposes a glaring contradiction between modern investing and the historic rules for denominating investment return as principal or income, yet the law clings steadfastly to the ancient distinction. Clinging to the ancient distinction is not only misguided, it is pernicious, for it ensures that trusts will earn lower returns. A requirement to earn income invariably forces trustees to earn interest in some large portion, and thereby forego earning capital gain on equities, which historically have exceeded interest on fixed income securities. The trustee must "accept a lower total return in order to obtain a particular form of return". 68

66 Jones above n 2, 699-700.

67 Jones above n 2, 712-713.

"Uniform Prudent Investor Act" above n 1, 668 (italics in original). 


\section{CONCLUSION}

Trustee investing is in the midst of a sea change. Until very recently, a trustee was either provided a list of authorised investments (the "legal list" approach prevailing in New Zealand prior to 1988) or told to evaluate each investment on its individual merits and be held liable if any individual investment was imprudent (the "prudent person" standard prevailing under US law). During the last 30 years, the theory of efficient markets has demonstrated the futility, even folly, of selecting individual equity investments. Instead, investors, including trustees, should assemble diversified portfolios to eliminate all firm-specific risk, leaving the investor exposed only to market risk. The investor should design the market risk of the portfolio, measured by beta coefficient, to be less than, equal to, or greater than the market risk of the general market depending on whether the investor wants higher safety or higher yield. The integration of modern portfolio theory into trustee investment law, like all changes in the law, will occur in fits and starts, yet the High Court decision in Mulligan makes a significant movement toward MPT-based investing. In Mulligan the trustees there were told they should have invested in a portfolio of equities with a beta of 0.75 , since when assessing damages the trustees were surcharged with a return on equities equal to $75 \%$ of the return of the Barclays Index.

The greatest concern to advisers to trustees in times of tumult, soon here if not here now, is the lack of certainty. The strong reaction to the Mulligan case, noting its "frightening implications," 69 demonstrates the concern with uncertainty in an area thought as well settled as trustee investing. Consequently, the pressure will be on the drafter to obviate the uncertainty of the default rules by writing an investment strategy into the deed of trust. It is perhaps a defect in modern trust practice that the goals of a trust rarely are stated in the trust instrument. ${ }^{70}$

A drafter could provide settlers with a checklist of three investment strategy options. ${ }^{71}$ The first option would give all investment return (whether realised as dividends, interest, or capital gain) to the income beneficiaries and simply provide the remainder beneficiaries with the nominal amount of the initial corpus. This option would not protect the remainder beneficiaries against inflation, but that direction might reflect the desires of many settlers, if the defence experts in Mulligan correctly stated that the normal practice of trustees (which presumably reflects normal settler intent) is to do

69 See above $\mathrm{n} 13$.

70 Kerry Ayers Fiduciary Obligations in Express Trusts [1997] NZLJ 243, 245. "Defeating the Duty" above $\mathrm{n} 30,77$.

71 "Modern Financial Theory" above n 33, 61. 
nothing positive about inflation. A second option directs the trustee to preserve the value of the initial property of the trust against price inflation, by allocating to principal an amount of investment return equal to inflation. Any amount of investment return in excess of inflation would be distributed to the income beneficiaries. A third option is the unitrust which uses a spending formula rather than "income" as the share of current-year distribution. ${ }^{72}$ A unitrust formula can be either a fixed percentage (5\%), a floating percentage (inflation plus $2 \%$ ), or a blended average ("the average investment return on the trust property for the past three years"). Lastly, if a settler wants particular assets (eg, family farm or shares in a family business) retained in the trust, a prudent drafter will affirmatively state that the trustee is under no duty to diversify with respect to those assets. While arguably there is no "duty to diversify" under the Trustee Amendment Act $1988,{ }^{73}$ a trustee who does not diversify acts at her peril. ${ }^{74}$ Hindsight likely will demonstrate that underdiversifying produced lower returns, as MPT tells us that underdiversifying usually exacts a price, just as it did in Mulligan. A careful trustee will not want to be told by a judge, after the fact, as the corporate trustee in Mulligan was told, that it should have sought court direction about whether to diversify when the settler was silent on the point. When MPT-based investing is in full flower, such uneconomic settler restrictions may be given less deference, but still a setter direction to retain certain trust property is far better than a trustee decision, not "directed" by a settler, not to diversify. Diversification will increasingly be seen as paramount to the interest of all beneficiaries.

72 Joel C Dobris "Modern Portfolio Theory, and College, University, and Foundation Decisions on Annual Spending from Endowments: A Visit to the World of Spending Rules" (1993) 28 Real Prop Probate \& Trust J 49.

73 Kerry Ayers reviewing R L Davis and G Shaw "Trustee Investment: The Prudent Person Approach" (1997) 486 LawTalk 77.

74 A recent decision of the Court of Appeal of New York, that state's highest court, ruled that failure to diversify is itself a violation of the prudent person investment standard. Estate of Janes $681 \mathrm{NE}$ 2d 332, 659 NYS 2d 165 (1997). The law of New York is exceptionally important in the development of US trust law because of the significant amount of economic activity and trust activity centered there. 